sciendo Порівняльна професійна педагогіка 9(3)/2019 Comparative Professional Pedagogy 9(3)/2019

DOI: $10.2478 /$ rpp-2019-0023

Postgraduate Student, DMYTRO KHRAPACH

Khmelnytskyi National University

Address: 11 Instytutska St., Khmelnytskyi, 29016, Ukraine

E-mail: hrapachdima@ukr.net

Doctor of Science in Pedagogy, Associate Professor, HANNA KRASYLNYKOVA

Khmelnytskyi National University

Address: 11 Instytutska St., Khmelnytskyi, 29016, Ukraine

E-mail:krasil@ukr.net

\title{
COMPARATIVE ANALYSIS OF DUAL EDUCATION IN GERMANY AND UKRAINE: APPROACHES AND MODELS
}

\begin{abstract}
The article presents the results obtained from a comparative analysis of the introduction of dual education in Germany and Ukraine. The European tendency towards transforming dual learning from vocational education to higher education is described. It is found that the conceptual basis for the introduction of dual learning is the cooperation between employers, educational institutions and students (employees), who are actively involved in learning, work and development of learning programmes for future specialists. The article discloses certain approaches to dual learning in Germany: combining learning in educational institutions with on-the-job learning, a focus on vocational training, being involved in the development of educational vocational programmes for social partners and the coordination of these programmes with all stakeholders. It also analyzes the main models of dual learning in German higher education institutions: learning-and practice-integrated studies. The learning-integrated model of dual learning includes the following characteristics: theoretical learning in a higher education institution is combined with simultaneous practical learning at an enterprise; such learning should result in obtaining a bachelor's degree, as well as a document upon the acquisition of practical skills in a particular profession, issued by the Chambers of Commerce and Industry of Germany. The practice-integrated model of dual learning is characterized as follows: theoretical learning in higher education institution, which is combined with different options for practical activities at the enterprise (practical learning, internships, part-time job or part-time learning). The article also considers the programmes of dual learning in certain German institutions offering dual learning and characterizes the peculiarities of their content. It also presents the results of a comparative analysis on bachelor programmes in the field of motor transport of related specialties in Ukraine and Germany, describes the conditions of dual education in Ukraine and outlines the prospects for its further development.

Keywords: dual education, dual learning, approaches to dual learning, elements of dual learning, models of dual learning, principles of dual learning, dual learning in higher education of Germany, dual learning programmes, dual systems.
\end{abstract}

\section{АНОТАЦІЯ}

У статті наведені результати порівняльного аналізу впровадження дуальної форми здобуття вищої освіти у Німеччині та Украӥні. Схарактеризована 
європейська тенденція трансформації дуального навчання із професійної освіти у вищу. Встановлено, що конщептуальною засадою запровадження дуального навчання $\epsilon$ співпраця трьох учасників освітнього процесу - роботодавия, закладу освіти та студента (працівника), які беруть активну участь у навчанні, роботі та формуванні програм підготовки майбутнього фахівия. Висвітлені підходи до дуального навчання в Німеччині: поєднання навчання в закладах освіти з навчанням на робочих місиях, акиент на професійну підготовку, залучення до розроблення освітніх професійних програм сочіальних партнерів та погодження програм з усіма зачікавленими сторонами. Виокремлені основні моделі дуального навчання у німецьких закладах вищій освіті: орієнтована на навчання та практико-інтегрована. Висвітлені особливості орієнтованої на навчання дуальної моделі: теоретичне навчання у закладі вищої освіти поєднується з одночасним практичним навчання студента на підприємстві; кінцевим результатом навчання студента є здобуття ступеня бакалавра та документа про набуття практичних навичок з певного фаху, який видає Торговопромислова палата Німеччини. Особливості практико-інтегрованої моделі дуального навчання є організачія теоретичне навчання у вищій школі, щзо комбінується з різними варіантами практичної діяльності на підприємстві (проходження практики, стажування, погодинна робота або часткова зайнятість студента). Наведені програми дуального навчання в окремих німецьких закладах дуального навчання та висвітлені особливості їх змісту. Виконано порівняльний аналіз освітніх програм підготовки бакалаврів в галузі автомобільного транспорту суміжних спеціальностей в Україні та Німеччині. Дана характеристика стану розвитку дуальної форми здобуття вищоӧ освіти в Україні та окреслені перспективи ї̈ подальшого розвиту.

Ключові слова: дуальна форма здобуття освіти, дуальне навчання, підходи до дуального навчання, елементи дуального навчання, моделі дуального навчання, принципи дуального навчання, дуальне навчання в вищій освіті Німеччини, дуальні навчальні програми, дуальні системи.

\section{INTRODUCTION}

The fundamental rapprochement and gradual integration of Ukraine into the European Union, as well as the functioning under the conditions of the European Higher Education Area, change the philosophy of the Ukrainian higher education system, the concept of its further development and promote its modernization. According to Art. 9 of the law of Ukraine "On Education" (2017), dual learning is defined as one of those needed to obtain an education, which includes combining full-time learning and on-the-job learning at enterprises, institutions and companies to acquire a certain qualification (Pro osvitu, 2017).

In Ukraine, dual learning was first introduced in vocational education in the late 1990 s through the creation of model centres for training future entrepreneurs (training companies) (Vyshche profesiine uchylyshche № 25, 2019). Therefore, this form of learning is envisaged by the draft of a new law of Ukraine "On Vocational (Vocational) Education" (2018) (Ministerstvo osvity i nauky Ukrainy, 2018). However, it has never been introduced in Ukrainian higher education institutions (HEIs) and, therefore, the creation of its legal framework in Ukraine has only recently begun (Ministerstvo osvity i nauky Ukrainy, 2019).

However, the study on the trends in the development of education abroad shows that in Europe over the last twenty years, vocational training of specialists has been provided by HEIs. Besides, the higher education system has expanded not owing to universities (Type A), but higher vocational institutions (Type B). In practice, this has led to the emergence of a large number of polytechnic and other vocational institutes, which are the basis of higher vocational education (Puukka, 2012). Also, there is a tendency to create 
sciendo Порівняльна професійна педагогіка 9(3)/2019 Comparative Professional Pedagogy 9(3)/2019

higher vocational institutions at classical European universities, which offer high-quality artisanal training in a particular field, which replaces the traditional vocational education system with a new segment of higher education (Type C) (Debych, 2013). According to some experts (Krasylnikova, 2015, p. 27), such a situation is caused by the dissemination of competency-based approach in higher education and the strengthening of the links between the education sector and the labour market.

A striking example of these changes in the European Higher Education Area in Germany, which, in the mid-1960s, introduced a new form of vocational education organization and first used the term "Duales Studium" for its definition (Boichevska, 2009). Concerning the term "Duales", the Great German-Ukrainian Dictionary translates it as "double" and "Studium" as "studies" (Miuller, 2005). The English-Ukrainian dictionary of terms (Balla, 1996) translates "dual" in the same way. Thus, it becomes clear that the authors of the dictionary (BIBB, 2014) define the term "dual learning" as a combination of educational models: acquiring theoretical and practical knowledge simultaneously. To this day, however, the term defining the meaning of this concept has not been established and, therefore, other terms are used along with "dual learning", including "dual system", "dual education", " the system of dual education", etc.

Consequently, the accumulated years of experience in the use of dual learning, both in vocational and higher education in Germany (Dernova, 2014), is valuable for Ukraine, especially now that the draft regulations on the dual form of higher and vocational higher education (Ministerstvo osvity i nauky Ukrainy, 2019) have been discussed in the Verkhovna Rada.

THE AIM OF THE STUDY

The article aims to identify the peculiarities of using dual learning at German universities and justify the possibility of using innovative ideas of German experience in the higher education system of Ukraine.

\section{THEORETICAL FRAMEWORK AND RESEARCH METHODS}

The analysis of literary sources on the problem under study shows that dual learning in the post-Soviet space has been studied by many scholars (N. Abashkina, S. Amelina, V. Anishchenko, S. Batyshev, H. Fedotova, N. Nychkalo, A. Piskunov, $\mathrm{V}$. Radkevych et al). Theoretical and scientific-practical elaborations in the system of vocational education organization based on the methodological principle of duality are contained in the writings of certain German scholars (A. Lipsmeyer, A. Schelten, H. Stegmann). The essence of dual learning has been revealed by D. Boud, K. Costley, I. Cunningham, D. Garnett, D. Relin, N. Solomon, B. Workman et al.).

The following methods were used to realize the aim of the study: analysis of Ukrainian and German regulatory documents on higher education, scientific articles and reports on the problem under study; synthesis; generalization of the obtained results.

\section{RESULTS}

The management of education in the Federal Republic of Germany is decentralized, and the norms and documents developed at the state level exist in the form of a framework. Therefore, the responsibility for the implementation of education policy rests with 16 federal lands, each of which, according to the Constitution, has a ministry of culture. The current system of higher education in Germany consists of 379 institutions, among which are classical, technical and pedagogical universities, universities of applied sciences (Fachhochschulen), cooperative state university (Berufsakademien), dual colleges (Sysoieva, \& Krystopchuk, 2012). 
Classical universities usually offer a wide range of areas of study. Technical universities are characterized by technically oriented programmes. In universities of applied sciences, student learning implies studying the basics of engineering and economics, and programmes typically include one or two semesters of practical training. Institutions can be both public and private and implement dual learning in different forms and models. It must be noted that the decision to implement dual learning is the prerogative of the institution itself.

Despite the external diversity of dual programmes, dual learning is based on the conceptual principles of cooperation between the three parties (stakeholders) of the educational process, namely enterprises (employers), educational institutions and students (employees) who take an active part in learning, work and development of learning programmes for future specialists (Holzer, 2019). The scheme for the practical implementation of dual learning in higher education institutions in Germany is presented in Figure 1 (Nicola, 2018).

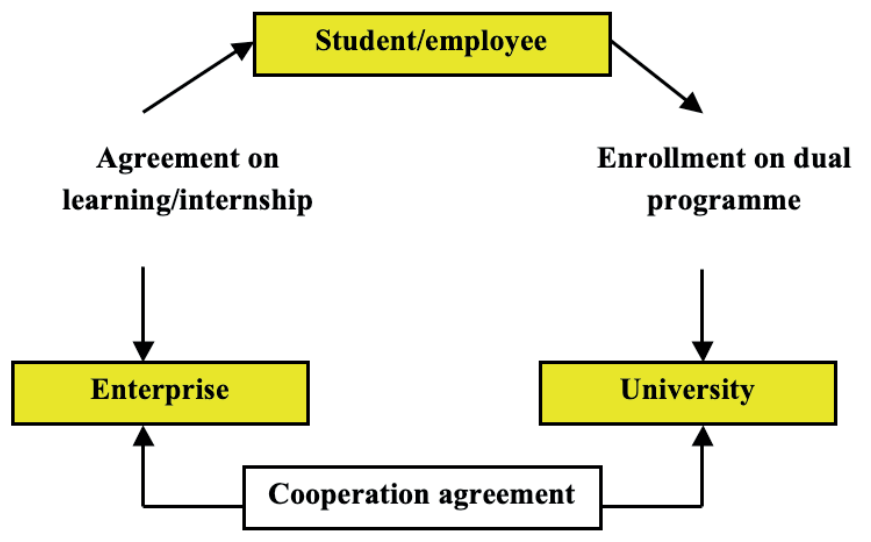

Fig 1. The scheme for the practical implementation of dual learning in higher education institutions in Germany

Therefore, a tripartite cooperation agreement (internship or temporary contract) is signed between the enterprise, the educational institution and the student for the duration of such learning. However, the basic conditions for the introduction of dual learning are the following: the presence of basic partner-enterprises, the development of a joint programme of interaction between the educational institution and the enterprise, the creation or allocation of student places, training grounds at the enterprise, the introduction of in-service training for teachers in special subjects, etc.

The process of dual learning is based on such basic principles as fundamentality, integration, versatility, continuity and consistency of stages and stages of vocational education, flexibility and variability of the content and technologies of the educational process, adaptability, a developmental character of education, democratization, interaction between theory with practice, research nature of teaching (Dzhamanbalin, Ryspaev, \& Olkinyan, 2018).

According to the resolution of the Main Committee of the Federal Institute for Vocational Training of Germany (BIBB) as of 21 June 2017, there are three main approaches to dual learning (Bundeszeiger, 2017):

- combining education with on-the-job learning;

- a key focus on vocational training; 
Sciendo Порівняльна професійна педагогіка 9(3)/2019

Comparative Professional Pedagogy 9(3)/2019

- involving social partners in the development of educational vocational programmes and coordinating these programmes with all stakeholders.

It must be noted that different models of dual learning are used for different levels of education (vocational education, higher education, adult education) (Bundeszeiger, 2017). Thus, vocational education normally offers the models of integrated learning and integrated practical learning; adult education - the integration of practice, research and on-the-job training. According to the recommendations of the Scientific Council (Wissenschaftsrat) of the BIBB as for developing vocational programmes, the following two models are common in higher education:

- learning-integrated studies (ausbildungsintegrierend Vorbereitung) - theoretical learning in a higher education institution is combined with simultaneous practical learning at an enterprise; such learning should result in obtaining a bachelor's degree, as well as a document upon the acquisition of practical skills in a particular profession, issued by the Chambers of Commerce and Industry of Germany;

- practice-integrated studies (praxisintegrierend Vorbereitung) - theoretical learning in higher education institution, which is combined with different options for practical activities at the enterprise (practical learning, internships, part-time job or part-time learning) (Holzer, 2019).

To enrol in a state-sponsored dual learning programme, one must either pass a matriculation exam (the Abitur) or obtain a special qualification for university entry. At private universities, the entrant first enrolles in a dual learning programme and, subsequently, chooses a relevant enterprise (company). Partner companies rather promote dual learning among young people and actively cooperate with educational institutions. From year to year, enrollment requirements for dual learning programmes are increasing, as well as the competition between them during the enrollment campaign.

Baden-Württemberg Cooperative State University, which was first to offer dual study programmes, was founded in the federal state of Baden-Württemberg in the 1970s. In 2009, all the land establishments of this type were merged into the first Duale Hochschule Baden-Württemberg, DHBW, which today cooperates with more than nine thousand partners, namely industrial enterprises and non-profit organizations in the field of business management, engineering and social services (Baden-Wuerttemberg Cooperative State University (DHBW), 2019). The DHBW only offers job integrated learning (JIL) programmes with mandatory internships or company work throughout the programme. The three-year JIL programmes are divided into three-month stages, alternating between university and business, and are based on tripartite employment agreements between the student, the institution and the partner company.

Gradually, the concept of dual learning has spread to other federal lands. Therefore, dual learning programmes today are offered by universities of applied sciences in almost all federal lands. One of the new state-owned universities is the University of Applied Sciences Ruhr West (Hochschule Ruhr West), located in Mülheim an der Ruhr in North Rhine-Westphalia. It provides engineering, mathematics and computer science education and offers dual learning programmes for future specialists by combining student learning and research in modern university laboratories with practical training based on the potential of regional economics and industry through the implementation of joint industry projects. The University implements its curricula using the two above-mentioned models of dual learning (see Table 1) (Holzer, 2019). 
sciendo Порівняльна професійна педагогіка 9(3)/2019 Comparative Professional Pedagogy 9(3)/2019

Table 1

The list of dual learning programmes in the University of Applied Sciences Ruhr West

\begin{tabular}{|c|l|c|c|}
\hline \multirow{2}{*}{ No } & \multicolumn{1}{|c|}{ Names of programmes } & \multicolumn{1}{|c|}{ Models of dual learning } \\
\cline { 3 - 4 } & & \multicolumn{1}{|c|}{1} & 2 \\
\hline 1 & Applied Computer Science & + & + \\
\hline 2 & Civil Engineering & + & + \\
\hline 3 & Business Administration - Industrial Service Management & + \\
\hline 4 & $\begin{array}{l}\text { Business Administration - International Trade Management, } \\
\text { Logistics }\end{array}$ & & + \\
\hline 5 & Electrical Engineering & + & + \\
\hline 6 & Energy and Water Management & + & + \\
\hline 7 & Energy Computer Science & + & + \\
\hline 8 & Car Electronics and Electric Mobility & + & + \\
\hline 9 & International Economy - Emerging Markets & + & \\
\hline 10 & Engineering & + & + \\
\hline 11 & Mechatronics & + & + \\
\hline 12 & Human-Computer Interaction & + & + \\
\hline 13 & Business Computer Sciences & + & + \\
\hline 14 & Industrial Engineering - Construction & + & + \\
\hline 15 & Industrial Engineering - Power Systems & + \\
\hline 16 & Industrial Engineering - Mechanical Engineering & + & + \\
\hline
\end{tabular}

Notes: Models of dual learning: 1 - learning-integrated model; 2 - practice-integrated model.

For one, the bachelor degree programme in Car Electronics and Electromobility is allocated 210 ECTS. The following options are available for this programme: 7 semesters full-time study and 9 semesters - dual learning following one of two models. During the implementation of the first dual learning model, students undergo theoretical training during the first two semesters -12 ECTS, during the third and fourth semesters - 18 ECTS. The rest of the study time is dedicated to practical training. After a one-year practical training at the enterprise, students take the intermediate examination in the Chamber of Commerce. The subsequent nine months result in the final examination at the Chamber of Crafts (die Handwerkskammern, HWK). Between the fifth and seventh semesters, students are expected to undergo theoretical training (30 ECTS) and complete projects on car electronics and sensors. Starting from the seventh semester, students are entitled to choose one of the optional modules. The last two semesters (eighth and ninth) consist of practical training (25 ECTS) and practical seminars (2 ECTS). The ninth semester involves writing and defending the bachelor thesis (12 ECTS) and colloquiums (3 ECTS).

In turn, the practice-integrated model of dual learning is characterized by systematic practical training at the enterprise for nine semesters, combined with theoretical training (18 ECTS per semester). It also results in the defence of the bachelor thesis. As a rule, graduates become employees of the enterprise where their practical training took place.

The introduction of dual education in Ukraine began with the development of a regulatory framework by the Ministry of Education and Science of Ukraine, namely the draft regulation on a dual form of higher and vocational pre-higher education and a standard agreement. At this stage, the readiness of higher education institutions to participate in the pedagogical experiment is extremely important. One of these institutions, which has been 
sciendo Порівняльна професійна педагогіка 9(3)/2019 Comparative Professional Pedagogy 9(3)/2019

implementing the elements of dual learning in the specialty 015.20 "Vocational education. Transport" since 2012, is Khmelnytskyi National University.

The curriculum is designed for eight semesters of full-time study (240 ECTS). Between the fifth to sixth semesters, students combine theoretical training at the university (4 days per week) with vocational training in production (one day per week). The partner companies in different years were the leading companies in the field of maintenance and repair of passenger cars in Khmelnytskyi, namely Leader Service Ltd. and Khmelnytskyi-Avto.

The experience of using dual learning indicates that there are significant advantages over the traditional model of studies. They include eliminating the gap between theory and practice, enhancing students' motivation to acquire practical knowledge and skills; increasing the interest of enterprise managers in practical training of potential employees; ensuring an interaction between the educational institution and the enterprise taking into account the requirements put forward by employers to future specialists during their training, etc.

The system of dual learning meets the interests of all participants in the educational process, namely the labour market (enterprises), students, educational institutions: enterprises - they can hire the specialists, whose training meets the necessary requirements, students - they can obtain an in-demand profession and easily adapt to professional activities; educational institutions - they can help to solve the problem of training qualified specialists for the country's economy. Still, the combination of study and work can lead to increased physical and mental efforts of students during their studies, narrowing their choice of educational courses, decreasing the level of research, which can be attributed to disadvantages.

\section{CONCLUSIONS}

Therefore, dual learning promotes the acquisition of great practical experience while studying at the enterprise, which contributes to better youth employment and further professional development. The results of the study on German experience of dual higher education shows that the combination of theoretical and practical training enables students to adapt more quickly in the labour market and allows employers to hire the best student trainees.

Further research should be dedicated to a more detailed study on the peculiarities of applying the existing models of dual education in Germany so that one can provide relevant recommendations on the use of innovative ideas of German experience in the higher education system of Ukraine.

\section{REFERENCES}

1. Baden-Wuerttemberg Cooperative State University (DHBW). (2019). Retrieved from http://www.dhbw.de/english/home.html.

2. Balla, M. I. (1996). Anhlo-ukrainskyi slovnyk (T. 1-2). Kyiv: Osvita.

3. BIBB. (2014). Dualnaya systema obucheniya: russko-nemetskiy slovar-spravochnik. Vzyato s https://docplayer.ru/36278699-Dualnaya-sistema-obucheniya-russko-nemeckiyslovar-spravochnik-duales-ausbildungssystem.html.

4. Boichevska, I. (2009). Rol systemy dualnoi osvity u profesiinii pidhotovtsi molodi u Nimechchyni. Porivnialno-pedahohichni studii, 2. Vziato z http://pps.udpu./ edu.ua/article/view/18067/15815.

5. Bundeszeiger. (2017). Bundesinstitut für Berufsbildung. Empfehlung des Hauptausschusses des Bundesinstituts für Berufsbildung vom 21. Juni 2017 zum dualen Studium. Retrieved from https://www.bibb.de/dokumente/pdf/HA169.pdf.

6. Debych, M. (2013). Evoliutsiia vyshchoi osvity na zlami stolit ta perspektyvy yii rozvytku. Vyshcha osvita Ukrainy, 4, 107-113. 
Sciendo Порівняльна професійна педагогіка 9(3)/2019 Comparative Professional Pedagogy 9(3)/2019

7. Dernova, M. (2014). Dualna model vyshchoi profesiinoi osvity doroslykh: yevropeiskyi dosvid. Osvita doroslykh: teoriia, dosvid, perspektyvy, 2 (9), 137-145.

8. Dzhamanbalin, K. K., Ryspaev, K. S., \& Olkinyan, L. Yu. (2018). Vnedrenie tsyfrovykh tekhnologiy v dualnoy sisteme vysshego obrazovaniya. Kostanay: KSTU.

9. Holzer, B. (2019). Duales Studium an der Hochschule Ruhr West. Retrieved from https://www.hochschule-ruhr-west.de/fileadmin/user_upload/01_Studium/Studienangebot/ Duales_Studium/Flyer_dual_HRW.pdf.

10. Krasylnikova, $\overline{\mathrm{H}}$. V. (2015). Monitorynh yakosti profesiinoi pidhotovky inzheneriv shveinoi haluzi u vyshchomu navchalnomu zakladi: teoretychni ta metodychni zasady. Khmelnytskyi: KhNU.

11. Ministerstvo osvity i nauky Ukrainy. (2018). Pro profesiinu (profesiinotekhnichnu) osvitu: proekt Zakonu Ukrainy vid 20.09.2018. Vziato z https://mon.gov.ua/ ua/news/mon-proponuye-do-gromadskogo-obgovorennya-proekt-zakonu-ukrayini-proprofesijnu-profesijno-tehnichnu-osvitu/.

12. Ministerstvo osvity i nauky Ukrainy. (2019). MON proponuie dlia hromadskoho obhovorennia proiekt polozhennia pro dualnu formu zdobuttia vyshchoi ta fakhovoi peredvyshchoi osvity ta typovyi dohovir pro zdobuttia vyshchoi, fakhovoi peredvyshchoi osvity za dualnoiu formoiu. Vziato $\mathrm{z}$ https://mon.gov.ua/ua/news/monproponuye-dlya-gromadskogo-obgovorennya-proyekt-polozhennya-pro-dualnu-formuzdobuttya-vishoyi-ta-fahovoyi-peredvishoyi-osviti-ta-tipovij-dogovir-pro-zdobuttyavishoyi-fahovoyi-peredvishoyi-osviti-za-dualnoyu-formoyu.

13. Miuller, V. (2005). Velykyi nimetsko-ukrainskyi slovnyk - blyzko 170000 sliv ta slovospoluchen. Kyiv: Chumatskyi shliakh.

14. Nicola, P. (2018). Dualne navchannia. Vziato z https://www.studis-online.de/ StudInfo/duales_studium.php.

15. Pro osvitu. № 2145-VIII. (2017).

16. Puukka, J. (2012). Post-secondary vocational educationand training: pathways and partnerships. Paris: OECD.

17. Sysoieva, S. O., \& Krystopchuk, T. Ye. (2012). Osvitni systemy krain Yevropeiskoho Soiuzu: zahalna kharakterystyka. Rivne: Ovid.

18. Vyshche profesiine uchylyshche No 25. (2019). Istoriia uchylyshcha. Взято 3 http://vpu25.km.ua/pro-nas/istoriya-uchylyscha/.

DOI: $10.2478 / \mathrm{rpp}-2019-0024$. 